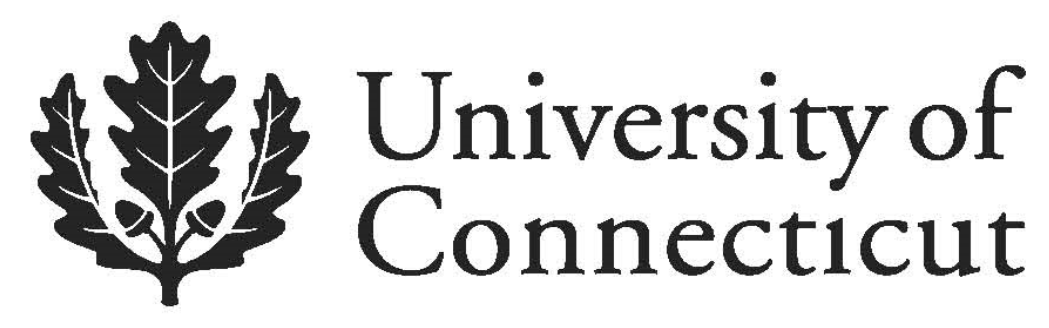

Department of Economics Working Paper Series

Homeowners, Renters and the Political Economy of Property Taxation

Eric J. Brunner

University of Connecticut

Stephen L. Ross

University of Connecticut

Rebecca K. Simonsen

Columbia University

Working Paper 2013-30

October 2013

365 Fairfield Way, Unit 1063

Storrs, CT 06269-1063

Phone: (860) 486-3022

Fax: (860) 486-4463

http://www.econ.uconn.edu/

This working paper is indexed on RePEc, http://repec.org 


\title{
HOMEOWNERS, RENTERS AND THE POLITICAL ECONOMY OF PROPERTY TAXATION
}

\author{
Eric J. Brunner, Stephen L. Ross, Rebecca K. Simonsen*
}

\begin{abstract}
Many economists have cited fiscal illusion as an argument against specific types of taxes arguing that less visible taxes may cause voters to systematically underestimate the true burden of taxation. The higher willingness of renters to support an increase in the property tax, often referred to as renter illusion, is often used as one of the classic examples of fiscal illusion. In this paper we use detailed micro-level survey data of registered voters in California to provide new evidence on the renter illusion hypothesis. The survey data contains voter responses to two key questions: 1) their willingness to pay higher property taxes to expand funding for public services and 2) their willingness to pay higher sales taxes to fund those services. Using a difference-in-differences estimation strategy to control for individual specific preferences for public service spending, we find first that renters are approximately 10 to 15 percentage points more likely than homeowners to favor a property tax increase over a sales tax increase to fund public services. However, further analysis indicates that our results are not driven by the voting behavior of renters. Results based solely on the sample of renters indicate that renters are indifferent between a property tax increase and a sales tax increase. In contrast, homeowners strongly oppose a property tax increase relative to a sales tax increase. These results cast doubt on the strong version of the renter illusion hypothesis that suggests renters believe they do not pay the property tax. Further analysis reveals that the strong opposition among homeowners to the property tax is not associated with the relative tax burden faced by homeowners. Examining the variation in tax burden created by Proposition 13 in California, we find that homeowner aversion to the property tax does not increase with the homeowner's relative tax burden. These findings of homeowner aversion to property taxes are consistent with recent work suggesting that salience matters when voters evaluate taxes, but also suggest that increased salience does not necessarily lead to more careful consideration of individual tax burdens.
\end{abstract}

Key words: fiscal illusion, renter effect, tax salience, tax burden, property tax JEL: H2, H7, R5

\footnotetext{
* Brunner: Department of Public Policy, University of Connecticut, 1800 Asylum Ave, 4th Floor, West Hartford, CT 06117, eric.brunner@uconn.edu; Simonsen: Student, Columbia University, rks2131@columbia.edu; Ross: Department of Economics, University of Connecticut, 341 Mansfield Road, Unit 1063, Storrs, CT 06269-1063, Stephen.L.Ross@uconn.edu.
} 


\section{Introduction}

Economists and policymakers have long been interested in how the visibility and salience of taxes affects taxpayer behavior and the size of government (Oates, 1988; Finkelstein, 2009). Recently, a series of influential papers have provided intriguing empirical evidence on how tax salience affects the political economy of taxation and taxpayer behavior. Cabral and Hoxby (2012) provide evidence that property tax rates tend to be higher in areas where the property tax is less salient while Finkelstein (2009) finds that the adoption of electronic toll collection (which reduces the salience of toll rates) leads to higher equilibrium toll rates. Chetty, Looney, and Kroft (2009) document that when consumers are presented with the sales tax inclusive price of goods (as opposed to the less salient net of sales tax price) demand for those goods falls. In an experimental context, Sausgruber and Tyran (2005) document that subjects overwhelmingly tend to vote in favor of a tax redistribution proposal that is not in their self-interest when taxes are indirect (and thus less visible) but vote overwhelmingly against the same proposal when taxes are direct (and thus highly visible). ${ }^{1}$ These findings may be particularly important given the long standing argument that taxpayer choices may be sub-optimal when taxes are not salient because taxpayers underestimate the true costs associated with public services (Buchanan, 1967; Campbell, 2004; Caplan, 2001; Rothbard, 2002).

In this paper we provide new evidence on how tax salience affects the political economy of taxation by revisiting one of the most often cited forms of fiscal illusion, namely renter illusion. Local public goods are typically financed through the property tax and while the property tax is one of the most salient taxes paid by homeowners it is largely thought to be invisible to renters who never receive a property tax bill. Consequently, renters may believe they don't pay property taxes. Consistent with that notion, studies that examine the demand for public services financed through the property tax consistently find that renters are more supportive of public spending than homeowners. Indeed, the finding is so pervasive that Wallace Oates (2005) recently dubbed it the "renter effect."2 Furthermore, as noted by Oates (2005), the presence of a renter effect has important policy implications since it implies that public budgets could be inefficiently large in communities with high concentrations of renters, a point consistent with

\footnotetext{
${ }^{1}$ In a related experimental study, Sausgruber and Tyran (2011) document that inexperienced voters tend to vote in favor of indirect taxes on sellers as opposed to direct taxes on themselves, even when taxes on sellers result in an income loss to voters of roughly $20 \%$.

${ }^{2}$ Oates (2005) uses the term "renter effect" rather than "renter illusion" to acknowledge the fact that there are other explanations for why renters may support higher levels of public services than homeowners. For example, Martinez-Vazquez (1983) notes that because property taxes are typically levied in proportion to the value of a voter's home, renters, who tend to consume less housing than homeowners (even those of similar income), may face a lower tax-price for public services. Similarly, there is considerably debate concerning the proportion of a property tax increase that is shifted forward in the form of higher rents. See for example Carroll and Yinger (1994) and Tsoodle and Turner (2008). If property tax increases are not fully shifted forward, renters may rationally demand higher levels of public services because they face a relatively low tax price.
} 
arguments made by Buchanan (1967) among others that fiscal illusion resulting from non-salient taxation may result in an excessively large public sector.

Studies of the renter effect fall into two main groups. The first and largest group estimates demand functions for local public services by regressing per capita local expenditures on community income, tax price and a set of controls that includes either the fraction of renters or the fraction of homeowners. ${ }^{3}$ These studies typically find that the coefficient on the fraction of renters (homeowners) is positive (negative). The second group of studies use vote outcomes from local property tax or bond referenda to estimate demand functions for public goods using control variables similar to those used in the expenditure studies. ${ }^{4}$ Similar to the expenditure studies, these studies tend to find that fraction of yes votes cast in these referenda is positively (negatively) related to the share of renters (homeowners).

While the existing literature typically finds that renters demand higher levels of public spending than homeowners, it falls short on establishing whether that relationship is indeed casual. ${ }^{5}$ Establishing causality is problematic because most prior studies are based on aggregate cross sectional data where unobservables could bias estimates of the renter effect. For example, renters may have stronger unobserved preferences for public services than homeowners, suggesting that they would prefer higher levels of government spending regardless of whether that spending was financed with property, income or sales taxes. In addition, prior studies have been unable to discern whether the observed renter effect is due to fiscal illusion or whether it is a rational response of renters, homeowners or both to the relative taxprice for public services. As noted by Oates (2005), distinguishing between the two explanations requires detailed micro-level data that allows for the separate identification of the preferences of homeowners and renters and such data has typically not been available.

In this paper we address these limitations by turning to a rich body of micro-level survey data provided by the Public Policy Institute of California (PPIC) and the Field Poll. The surveys asked representative samples of California voters' two key questions: 1) whether they would be willing to pay higher property taxes to expand funding for public services and 2) whether they would be willing to pay higher sales taxes to expand funding for public services. The surveys also asked voters a rich set of

\footnotetext{
${ }^{3}$ Early studies include Bergstrom and Goodman (1973) and Lovell (1978). More recent studies include Rothstein (1994), Dollery and Worthington (1999) and Corcoran and Evans (2010). See Oates (2005) and Dollery and Worthington (1996) for a review of this literature.

${ }^{4}$ Examples include Martinez-Vasquez (1983), Biegeleisen and Sjoquist (1988), Rothstein (1994) and Brunner and Balsdon (2004). See Oates (2005) and Dollery and Worthington (1996) for a review of this literature.

${ }^{5}$ While the existing literature typically finds that renters demand higher levels of public spending than homeowners, there are a number of notable exceptions. Based on survey data, Schokkaert (1987) finds no evidence that renters are more willing to pay higher taxes than homeowners to support an expansion of local public services. Similarly, Schwab and Zampelli (1987), Reid (1991), Heyndels and Smolders (1994), Gemmell et. al. (2002), Blom-Hansen (2005) and Banzhaf and Oates (forthcoming) find no evidence of a renter effect.
} 
demographic questions including their income, age, educational attainment and most importantly, whether they were a homeowner or a renter.

Compared to the data used in prior studies, the survey data we utilize has a number of key advantages. First, because each survey contains a voter's response to a question regarding willingness to support a property tax increase and to a question regarding willingness to support a sales tax increase we can estimate models that condition out individual fixed effects. Specifically, we estimate a model where the dependent variable is the difference between a voter's support for a property tax increase and their support for a sales tax increase and the key independent variable is an indicator variable that takes the value of unity if the voter is a renter. This difference-in-differences specification allows us to control for any unobservable individual characteristics, such as tastes and preferences for public services, which might otherwise bias our estimates. Second, because we have micro-level data, we can also estimate separate models for renters and homeowners and thus explicitly account for any differences in the preferences of these two groups of voters by allowing the explanatory variables in our regressions to have different slopes as suggested by Oates (2005). ${ }^{6}$

Our analysis yields several important findings. First, based on the combined sample of homeowners and renters, we find robust evidence consistent with the presence of a renter effect. Our difference-indifferences estimates suggest that renters are approximately 10 to 15 percentage points more likely than homeowners to favor a property tax increase over a sales tax increase to fund public services. This effect is robust to the inclusion of county fixed effects to control for regional differences in the relative preference for property and sales taxes. The effect is also relatively homogeneous across both college educated and non-college educated renters, high and low income renters, and younger and older renters suggesting that the renter effect we identify is unrelated to typical proxies for financial sophistication such as education, income or age.

Second, our estimates based solely on the sample of renters suggest that renters are indifferent between a property tax increase and a sales tax increase to fund public services: a finding that is clearly inconsistent with the renter illusion hypothesis at least under the assumption that renters observe and expect to pay at least part of the sales tax. The fact that renters are indifferent between a property tax and a sales tax increase implies that the renter effect we identified in our analysis of the combined sample of homeowners and renters is being driven completely by the voting behavior of homeowners. Specifically,

\footnotetext{
${ }^{6}$ In the study closest to ours, Banzhaf and Oates (forthcoming) use aggregate vote returns from open space referenda to examine the renter illusion hypothesis. Similar to us, they attempt to isolate the renter effect by examining whether renters are more supportive of open space referenda financed through a property tax increase than open space referenda finance through a sales tax increase. However, because of the aggregate nature of their data, they are unable to estimate separate models for renters and homeowners and are thus unable to examine the mechanism behind their results.
} 
we find that while renters are indifferent between the sales tax and the property tax, homeowners are significantly more likely to support a sales tax increase to fund public services than a property tax increase.

Next, we investigate a natural alternative explanation for the observed opposition among homeowners to property taxation, namely whether homeowner opposition to the property tax is associated with facing a higher burden from property taxation than from sales taxation. To do so, we make use of an institutional detail of California, namely Proposition 13. The proposition, which became effective in 1978, prohibits the reassessment of homes for property tax purposes except when a home is sold. Consequently, homeowners that have lived in their residence for long periods of time face significantly lower property tax burdens than homeowners who purchased similar homes more recently. We exploit this differential in property tax burdens by examining whether homeowners that have lived in their current home for 10 years or more (or in other specifications 20 years or more) are more likely to support a property tax increase than homeowners who purchased their home more recently. We find that they are not. Homeowners who have lived in their home for long periods of time are just as opposed to property taxes as homeowners who recently purchased their home.

Finally, we examine whether the uniform response of homeowners to the property tax arises because homeowners are unaware of the details of their tax burden and thus simply oppose the property tax based on their general belief that as homeowners they likely face a higher tax burden than rental households in the same jurisdiction. The Field Poll asks several survey questions on Proposition 13. Using these responses, we show that homeowners who have lived in their homes the longest are more aware of Proposition 13 than either recent residents or renters. Furthermore, we find that long-term homeowners support Proposition 13 more strongly than homeowners who have been residing in their homes for less time, which unlike their response to the property tax is entirely consistent with their economic interests.

The lack of any correlation between the burden faced by apparently well-informed homeowners and their aversion to the property tax suggests that even though consumers appear to respond more strongly to salient taxes (Finkelstein, 2009; Chetty, Looney and Kroft, 2009; Sausgruber and Tyran, 2005; Blumkin, Ruffle, and Ganun, 2012; Cabral and Hoxby, 2012), such a strong response does not necessarily imply that the use of salient taxes leads to a more careful consideration of the individual burden associated with a tax increase as might be inferred from arguments by Buchanan (1967) and others. In our sample, California homeowners are clearly well aware of the property tax and the redistribution of tax burden under Proposition 13, and yet long tenure residents who on average pay a much smaller share of local expenditures on public services financed through the property tax are equally opposed to the use of that tax. 


\section{The PPIC and Field Poll Surveys}

In 1998 the Public Policy Institute of California (PPIC) initiated the Statewide Survey to provide policymakers and the public with information on voter sentiment concerning a wide range of economic and political events in California including ballot initiatives, local and state budgets and preferences for tax and expenditure packages. Each year the PPIC conducts approximately 8 to 10 surveys on a monthly basis with each survey containing responses from approximately 2,000 potential voters. The surveys are conducted by telephone (both landline and cell phone), using a random-dialing procedure, and are restricted to California residents age eighteen or older. ${ }^{7}$ Our primary analysis is based on surveys conducted in May of 2004, March of 2005 and April of 2006.

Our main analysis focuses on responses to four questions asked in these surveys. The first two questions focus on the willingness of voters to support additional state-level funding for K-12 education that would be financed either through a sales tax increase or a property tax increase. Specifically, respondents to the April 2006 survey were asked the following questions on a rotating basis to avoid bias associated with ordering effects:

Here are some ideas that have been suggested to raise state revenues to provide additional funding for California's K-to-12 public schools. For each of the following, please say if you favor or oppose the proposal.

How about raising the state sales tax? (Do you favor or oppose this proposal to raise revenue for state school funding?)

How about increasing property taxes? (Do you favor or propose this proposal to raise revenue for state school funding?)

The second two questions focus on the willingness of voters to support a local sales tax increase to provide additional funds for local government services, such as public safety, and their willingness to support a local property tax increase to provide additional funds for local public schools. Specifically, respondents to the May 2004 and March 2005 surveys were asked to following questions, once again on a rotating basis:

What if there were a measure on your local ballot to increase the local sales tax in order to fund local government services such as parks, police, and roads? Would you vote yes or no?

What if there were a measure on your local ballot to increase property taxes in order to provide more funds for the local public schools? Would you vote yes or no?

While the state and local versions of the property tax and sales tax questions are quite similar, there is one important difference. In the state-level funding questions, respondents were asked about their

\footnotetext{
${ }^{7}$ The PPIC compares the demographic characteristics of survey respondents with characteristics of the adult population from the Census and California state figures and has found that the surveys are representative of California's adult population.
} 
willingness to support either a property tax increase or a sales tax increase to fund a specific public good, namely K-12 education. Thus, the state level questions hold the public good in question constant while only varying the financing mechanism. In contrast, in the local-funding questions respondents were asked about their willingness to support a sales tax to fund general local government services (with some examples given) and a property tax to fund a specific local government service, namely K-12 education. Thus, in terms of the empirical work that follows, the local questions suffer from the disadvantage that estimates of the renter effect based on responses to those questions could be biased by any unobserved differences in renters and homeowners willingness to support general local government services versus $\mathrm{K}-12$ education specifically. Consequently, we view the state-level funding questions as providing the most direct evidence on the renter effect and utilize the local-level funding questions as additional robustness checks.

In addition to the surveys conducted by the PPIC, we also make use of a set of surveys conducted by the Field Poll during the 1990's. Similar to the Statewide Survey conducted by the PPIC, the Field Poll is designed to provide non-partisan information on public opinion trends in California. Operating continuously since 1947, the Field Poll typically conducts between four and seven surveys per year on a monthly basis with each survey containing voter responses from approximately 1,000 potential voters. ${ }^{8}$ We searched the Field Poll archives to identify any surveys that asked respondents both about their willingness to support higher property taxes to fund public services and their willingness to support higher sales taxes to fund public services. Based on that search we identified three separate surveys in which respondents were asked both questions. The surveys, which were conducted in August of 1990, November of 1991 and May of 1995, asked survey respondents the following questions:

If the State needed the money and taxes had to be raised, would you favor or oppose increasing taxes on residential property?

If the State needed the money and taxes had to be raised, would you favor or oppose increasing state sales taxes?

These Field Poll questions are quite similar in nature to the state-level funding questions asked by the PPIC; the obvious difference being that while the PPIC survey focused on voter willingness to support additional funding for K-12 education, the Field Poll surveys focus on voter support for state funding in general. Most importantly, similar to the state-level funding questions asked by the PPIC, the Field Poll

\footnotetext{
${ }^{8}$ Since 1956, the Field Poll has archived the results of its surveys at the University of California. The data is freely available at http://ucdata.berkeley.edu/. Until 2006, the Field Poll "employed a random digit dial sampling methodology when conducting surveys of either California adults or the state's registered voter population" (information obtained from http://www.field.com/fieldpoll/methods.html). Starting in 2006, the Field Poll began using registration-based lists of the state's voting population.
} 
questions hold the public good in question constant while only varying the financing mechanism, making them ideal for analyzing the differential level of support among homeowners and renters for property tax and sales tax increases.

Utilizing both the Statewide Survey results from the PPIC and the survey results from the Field Poll has a number of advantages. First, because the PPIC and Field Poll surveys were conducted by two independent survey research organizations and represent independent samples of California voters, comparing the results obtained from the different surveys provides a valuable robustness check. Second, given that the PPIC surveys we utilize were conducted in the mid 2000's while the Field Poll surveys we utilize were conducted in the early to mid 1990's, analyzing both provides us with a better sense of the inter-temporal validity of our results.

\section{Empirical Specification}

To examine how voter support for property tax and sales tax increases varies with housing tenure status we estimate the following model:

$$
\left(\text { yes }_{i}^{\text {Prop }}-y^{\text {es }}{ }_{i}^{\text {Sales }}\right)=\beta_{0}+\beta_{1} \text { Rent }_{i}+\beta_{2} X_{i}+\varepsilon_{i}
$$

where $y e s_{i}^{\text {Prop }}$ and $y e s_{i}^{\text {Sales }}$ are respectively indicator variables that take the value of unity if individual $i$ voted in favor of a property tax increase or a sales tax increase and the value of zero if the individual voted against such an increase, Rent $_{i}$ is an indicator variable that takes the value of unity for renters and zero for homeowners, $X_{i}$ is vector of demographic variables for individual $i$, and $\varepsilon_{i}$ is a random disturbance term.

The coefficient of primary interest in equation (1) is $\beta_{1}$, which measures the conditional average difference between renters and homeowners in their support for a property tax versus sales tax increase. A positive and significant value of $\beta_{1}$ provides evidence in favor of the renter effect. Note that equation (1) differences out any individual unobservables that may be correlated with the binary treatment variable, Rent $_{i}$ and the level of support for public services. Thus, our difference-in-differences estimator controls for any unobservable differences between renters and homeowner such as wealth, tastes and preferences for public service provision, etc., that might otherwise affect the demand for or tax price of public services and so bias our estimates. The inclusion of the additional control variables, $X_{i}$, in equation (1), allows us to further control for how observable demographic characteristics of renters and homeowners affect differences in support for property taxes and sales taxes. These controls are particularly relevant for our analysis of local funding where as we noted previously, respondents were asked about their willingness to support a sales tax to fund general local government services and their 
willingness to support a property tax to fund local K-12 education. Since the good in question is not held constant in this case, the inclusion of these additional controls should alleviate some of the concern that the renter variable is capturing unobserved differences between renters and homeowners in their willingness to support K-12 education versus general local government services.

\section{Data and Summary Statistics}

Table 1 lists the variables we use in our analysis and their mean values. We use the same set of variables to explain voting behavior related to state funding and voting behavior related to local funding. As noted previously, our primary variable of interest is an indicator variable that takes the value of unity if a respondent is a renter and zero if they are a homeowner. We also include a host of control variables, all of which are indicator variables. For the state and local funding questions asked by the PPIC, those variables include: 1) whether there are children under the age of 18 living in the respondent's household, 2) whether the respondent has children attending private school, 3) a set of three age indicator variables for whether the respondent is between the ages of 45 and 54, 55 and 64, and 65 or older (the omitted group is respondents under the age of 45), 4) whether the respondent has an associate degree or higher, 5) a set of four income indicator variables for whether a respondent's income lies between $\$ 40,000$ and $\$ 60,000, \$ 60,000$ and $\$ 80,000, \$ 80,000$ and $\$ 100,000, \$ 100,000$ or more (the omitted group is under $\$ 40,000), 6$ ) whether the respondent is female and 7) a set of racial/ethnic indicators for whether a respondent is Black, Hispanic or Asian (the omitted group is non-Hispanic Whites). All of these variables are designed to control for economic and demographic characteristics of respondents that might affect their preferences concerning the property tax, or in the case of the local spending survey questions, differences in the demand for public education spending relative to demand for other publicly provided services.

For the state-level funding questions asked by the Field Poll we include the same set of control variables with a few notable exceptions. First, because the Field Poll surveys did not ask respondents whether there were children under the age of 18 living in the respondent's household or whether the respondent had children that attended private school, we omit those two control variables. Given that the Field Poll questions pertain to voter support for general state funding (as opposed to support for K-12 education as with the PPIC surveys) the exclusion of these variables should have little impact on our results. Second, because the Field Poll surveys was conducted during the early to mid 1990's respondents' were asked to report their income based on income ranges that differed from those on the PPIC surveys. Thus, for the Field Poll survey we use a set of three income indicator variables for whether a respondent's income lies between $\$ 20,000$ and $\$ 40,000, \$ 40,000$ and $\$ 60,000$ and $\$ 60,000$ or more (the omitted group is under $\$ 20,000)$. 
The means for the variables listed in Table 1 are reported separately for the PPIC survey asking voters about support for state funding for K-12 education, the two PPIC surveys asking voters about support for local funding of public services and the three Field Poll surveys asking voters about support for general state-level funding. For each set of surveys, we also present separate means for the samples of renters and homeowners. A brief inspection of the table reveals several interesting facts. First, the means for the dependent variables reveal that renters are more likely than owners to support a property tax increase than a sales tax increase at both the state and local levels. Second, both renters and homeowners appear much more likely to support tax increases when those tax increases are designated for local funding. Third, support for sales tax increases varies little with housing tenure at both the state and local level.

Table 1 also reveals that renters and homeowners tend to differ significantly in terms of observables characteristics. As expected, renters tend to be younger, less educated, and have lower incomes than homeowners. They are also less likely to have children in private school and are significantly more likely to be Black or Hispanic. These differences in observable characteristics reinforce the notion that renters and homeowners are also likely to differ in unobservable ways that could influence preferences for public services and so potentially bias estimates of the renter effect in cross sectional studies.

\section{Results}

For comparison with the previous literature and to provide greater assurance that our survey data is representative, we begin by estimating simple cross sectional models, based on the PPIC surveys, that examine voter support for expanding state-level K-12 education funding or expanding local-level K-12 education funding that is financed through a property tax increase. Results are reported in Table 2 with robust standard errors in brackets. Column 1 presents results when the dependent variable is an indicator variable that takes the value of unity if a voter supports increasing property taxes to expand state funding for K-12 education while column 2 presents results when the dependent variable is an indicator variable for whether a voter supports increasing property taxes to expand local funding for K-12 education. The estimates reported in Table 2 are linear probability model estimates implying the estimated coefficients can be directly interpreted as marginal effects.

The results reported in Table 2 are largely consistent with expectations and the results found in the existing literature. First, our results indicate that renters are significantly more likely to support a property tax increase to fund public education than homeowners, a result that holds across both specifications. Specifically, our cross-sectional results suggest that renters are between 10 and 19 percentage points more likely to support a property tax increase than homeowners. Thus, consistent with the majority of the existing literature, we find evidence consistent with a "renter effect" in these crosssectional estimates. Second, consistent with the result of numerous studies that examine the demand for 
local education spending, we find evidence that older voters are significantly less likely to support spending on K-12 education. ${ }^{9}$ Third, consistent with expectations, households with children in private school are less likely to support spending on K-12 education.

\section{Difference-in-Differences Estimates}

Having established that our survey data yields results that are similar to those found in the existing literature, we now turn to results based on our preferred specification, namely the difference-indifferences specification given by equation (1). Those results are reported in Table 3 . In the interest of brevity we report only the estimated coefficient on the indicator variable for being a renter but note that all the specifications reported in Table 3 contain the full set of control variables listed in Table 1. As the first panel of Table 3 reveals, our difference-in-differences estimates are consistent with the presence of a renter effect: in all three specifications, the estimated coefficient on the renter variable is positive and statistically significant at the 1 percent level or better. Renters are approximately 10 percentage points more likely than homeowners to support a property tax increase over a sales tax increase to fund additional state spending on either K-12 education (column 1) or general state services (column 2) . Similarly, they are approximately 15 percentage points more likely than homeowners to support a property tax increase over a sales tax increase to fund additional local spending (column 3 ). The second panel of the table presents estimates based on models that add county fixed effects to the specifications. These county fixed effects control for any county level variation in differential support for property versus sales taxes. The inclusion of these fixed effects has little impact on our results. The estimated coefficients in panel 2 are similar in magnitude to those reported in panel 1 and remain statistically significant at the 5 percent level or better.

Panels 3 through 5 of Table 3 present the results of specifications where we interact the renter variable with variables representing groups of respondents which might be less prone to renter illusion: college educated voters, high income voters, and more experienced (older) voters. In panel 3, the renter variable is interacted with an indicator variable for respondents with a college degree or higher. The estimated coefficients on the renter variable demonstrate minimal change in the magnitude of the renter effect. Furthermore, the estimated coefficients on the interaction term are relatively small in magnitude and statistically insignificant. Panels 4 and 5 display a similar pattern. In panel 4 the renter variable is interacted with either an indicator for respondents with incomes of $\$ 60,000$ or more (PPIC surveys) or with an indicator for respondents with incomes of $\$ 40,000$ or more (Field Poll surveys) and in panel 5 the renter variable is interacted with an indicator for voters age 45 or older. In both panels we once again

${ }^{9}$ For recent examples see Figlio and Fletcher (2012), Reback (2011), Brunner and Ross (2010), Cattaneo and Wolter (2009), and Fletcher and Kenny (2008). 
find that the estimated coefficient on the renter variable is relatively stable and statistically significant while the estimated coefficient on the interaction term is statistically insignificant and relatively small in magnitude. Therefore, we find no evidence that the renter effect we have identified appears to be driven by the voting behavior of less educated, lower income or younger voters that may be differentially prone to fiscal illusion.

It is also worth noting the high degree of correspondence, both in terms of magnitude and statistical significance, between the state-level funding results from the PPIC survey (column 1) and the Field Poll surveys (column 2). Thus, our results provide evidence that the renter effect we have identified persists across surveys conducted by different organizations and across different time periods. In sum, our difference-in-differences estimates provide strong evidence consistent with the presence of a renter effect. Specifically, we find that renters are between 10 and 15 percentage points more likely to vote in favor of a property tax increase than homeowners. This effect is robust to the inclusion of county fixed effects and appears to be relatively homogeneous across both college educated and non-college educated renters, high and low income renters, and younger and older renters. The fact that more educated, older, and higher income renters appear to vote no differently than other renters, provides some initial evidence that the voting behavior of renters may not be due to fiscal illusion. Specifically, if our results were being driven by fiscal illusion we would expect less educated and younger renters to be more prone to such illusion. However, we find no evidence that they are. In the next section, we investigate the mechanism behind our results in more detail.

\section{Separate Estimates for Renters and Homeowners}

To examine the voting behavior of renters and homeowners in more detail, we estimate a specification similar to that of equation (1) except we split the sample based on whether a respondent is a renter or a homeowner and estimate separate regressions for the two groups of voters. By estimating separate regressions for renters and homeowners we can explicitly account for any differences in the preferences of these two groups of voters by allowing the explanatory variables in our regressions to have different slopes. Furthermore, estimating separate models for renters and homeowners allows us to directly examine whether the voting behavior of renters is driven primarily by fiscal illusion or some other mechanism. Specifically, it seems natural to assume that renters are well aware of the fact that they pay the sales tax. Thus, if fiscal illusion associated with the incidence of the property tax on renters is the explanation for our Table 3 results, we would expect renters to be more supportive of a property tax increase than a sales tax increase.

Table 4 presents results based on specifications where we split our sample based on whether a respondent is a renter or a homeowner. In the top panel we present results based on specifications where 
we simply regress the difference in support for a property tax increase versus a sales tax increase on a constant. The estimated coefficients thus represent the average difference in support for a property tax versus a sales tax increase for renters and homeowners, respectively. In the state funding specifications we find that, if anything, renters are less likely to support a property tax increase than a sales tax increase. Specifically, in columns 1 and 3 the estimated coefficients are negative and statistically significant at the $5 \%$ level, indicating that renters are less likely to support a property tax increase than a sales tax increase for either state-level funding of K-12 education (column 1) or general state services (column 3). That finding is clearly inconsistent with the renter illusion hypothesis. In the local funding specification (column 5) we obtain similar results. There we find that renters are indifferent between a property tax increase and a sales tax increase, a finding that is once again clearly inconsistent with the renter illusion hypothesis.

While renters appear relatively indifferent between a property tax increase and a sales tax increase, the results reported in columns 2, 4 and 6 reveal that homeowners clearly prefer a sales tax increase over a property tax increase. In the state funding specifications (columns 2 and 4), homeowners are 14 and 20 percentage points more likely to support a sales tax increase over a property tax increase and in the local funding specification they are 17 percentage points more likely to support a sales tax increase.

One concern with the results reported in the top panel of Table 4 is that they do not control for any demographic characteristics of renters and homeowners that might be correlated with a differential support for property taxes versus sales taxes. Consequently in the bottom panel of Table 4 we present results based on specifications where we also include all of the control variables listed in Table 1 . The control variables used in the bottom panel are mean differenced so that the intercept in these specifications measures the average difference in support for property taxes versus sales taxes when all the control variables are evaluated at their mean values. The inclusion of these control variables has little impact on our results. The estimated coefficients reported in the bottom panel of Table 4 are quite similar to those reported in the top panel.

The results reported in Table 4 strongly suggest that while renters appear to be rather indifferent between a property tax increase and a sales tax increase, homeowners strongly oppose a property tax increase relative to a sales tax increase. As noted above, if we assume renters are aware of the fact that they pay the sales tax, our results provide rather compelling evidence that renters do not suffer from fiscal illusion; at least not a strong version of fiscal illusion whereby renters believe they pay little or no property taxes. Our results also imply that the renter effect we identified in Table 3 is being driven completely by the voting behavior of homeowners. For example, our finding that renters are approximately 10 percentage points more likely to support a property tax increase than a sales tax increase (column 1, row 1 of Table 3 ) is explained entirely by the fact that in Table 4 we find that 
homeowners are 14 percentage points less likely and renters 4 percentage points less likely to support a property tax increase, the difference between those two estimates being 10 percentage points or the estimated coefficient in Table 3. Given that our controls include current income as well as other human capital variables such as age and education, the inclusion of these controls should address a key potential explanation for the apparent strong opposition among homeowners to the property tax, namely that homeowners' face a higher tax burden with property taxation than they do with sales taxation.

Further, we can address the concern about differential tax burdens more directly by making use of a unique institutional detail of California, namely Proposition 13. The proposition, which went into effect in 1978, prohibits the reassessment of homes for property tax purposes except when a home is sold. Consequently, homeowners that have lived in their residence for long periods of time face significantly lower property tax burdens than homeowners who purchased similar homes more recently. In Table 5 we exploit this differential in property tax burdens by examining whether homeowners who have lived in their homes for 10 years or more are more likely to support a property tax increase than homeowners who purchased their home more recently. ${ }^{10}$

Columns 1 and 2 of Table 5 reproduce the results from Table 4 for comparison purposes. Note that the Field Poll surveys we utilize did not ask respondents how long they have lived in their current residence and thus the analysis presented in Table 5 is based only on the PPIC surveys. Columns 3 and 4 add an indicator variable to the specifications that takes the value of unity if a respondent has lived in their current residence for 10 years or more. In three of the four specifications listed in column 4 the estimated coefficient on the indicator variable for living in current residence for 10 years or more is statistically insignificant and small in magnitude. Furthermore, in the one case where the estimate is statistically significant (panel 2) it is negative, suggesting that homeowners that have lived in their homes the longest are actually less supportive of a property tax increase relative to a sale tax increase. ${ }^{11}$

To examine the robustness of this result, in column 6 we also add an indicator variable for homeowners that have lived in their current residence for 20 years or more. The inclusion of this

\footnotetext{
${ }^{10}$ While California housing prices have a volatile history, prices on average rose significantly during this period with prices increasing between 2 and 3 times over the ten years and between 3 and 5 times over the twenty years preceding the surveys in our sample. These figures are calculated based on the Federal Reserve Bank of St. Louis state level housing price index data, which can be found at http://research.stlouisfed.org/fred2/series/CASTHPI. ${ }^{11}$ The negative and significant coefficient on the years in current residence variable found in panel 2 is most likely due to the fact that at the local level we are comparing voter support for a property tax to funding K-12 education and a sales tax to fund general local services, one of which is police. People that have lived in their homes for the longest period of time are most likely older and we would expect older voters to care more about police protection than K-12 education. Consequently, since the results reported in panel 2 contain no controls for age, the estimated coefficient on the years in current residence variable is most likely picking up elderly voter resistance to funding for $\mathrm{K}-12$ education relative to police. That interpretation is reinforced by the fact that the estimated coefficient on the years in current residence variable becomes small and insignificant once we control for age in panel 4.
} 
additional variable does not alter our main conclusion. Homeowners that have lived in the current residence the longest, appear to vote no differently than homeowners that purchased their homes more recently. ${ }^{12}$ We take these findings as suggesting that the strong opposition among homeowners to the property tax cannot simply be explained by the fact that homeowners' may face a higher tax burden with property taxation than they do with sales taxation. If that were the case, the inclusion of controls for income and education, which capture tax burden, should have at least eroded the estimated differences for homeowners. Further, homeowners that have lived in their current residence for long periods of time should be at least somewhat more supportive of property taxation than more recent homeowners due to the substantial redistribution of the property tax burden that arises under Proposition 13.

A second explanation for our results is that homeowners are unaware of the details of their tax burden and thus simply oppose the property tax based on their general belief that as homeowners they likely face a higher tax burden than rental households in the same jurisdiction. For example, homeowners may not be aware that Proposition 13 prohibits the reassessment of homes for property tax purposes except when a home is sold or that this provision implies that long-time resident homeowners face a much lower tax burden than other homeowners. To examine that possibility we analyzed the responses of California residents to the following two questions that were asked by the Field Poll in their May 2008 survey:

How familiar are you with proposition 13, approved thirty years ago in $1978 ?$

If proposition 13 were up for a vote again today, do you think you would vote in favor of it or against it?

It is important to note that prior to asking these questions, which appeared back to back on the survey in the order listed above, the Field Poll did not provide respondents with any background information on Proposition 13 or its effects. Thus, if homeowners who have lived in their home the longest are more likely than other homeowners to state that they are familiar with or that they would vote in favor of Proposition 13, we can be reasonably sure that this differential in support is being driven by genuine voter knowledge about Proposition 13 rather than information provided during the survey.

Table 6 provides cross tabulations of voter responses to the questions listed above. Columns 1 through 5 of the top panel show how familiarity with Proposition 13 varies with the length of time since a homeowner purchased their current home. Similarly, columns 1 through 5 of the bottom panel show how voter support for Proposition 13 varies with a homeowners years in current residence. The final two columns of the table show how familiarity with, and voter support for, Proposition 13 varies with tenure

\footnotetext{
${ }^{12}$ As an additional specification check, we also estimated the specifications presented in Table 4 using only the subsample of respondents with a Bachelor's degree or higher. Once again, this did not alter our main conclusion: homeowners that have lived in the current residence the longest appear to vote no differently than homeowners that purchased their homes more recently.
} 
status (owner or renter). A brief inspection of Table 6 reveals that homeowners that have lived in their current residence the longest are substantially more likely to be very familiar with Proposition 13 and substantially more likely to vote for Proposition 13 again than homeowners that recently purchased their home. In addition, homeowner are substantially more likely than renters to both respond that they are very familiar with Proposition 13 and would vote for it. In fact, $81.8 \%$ of all homeowners responded that they were either very familiar or somewhat familiar with Proposition 13.

Table 7 provides further evidence that homeowners are familiar with Proposition 13 and its ramifications. The table presents results based on a series of linear probability models designed to isolate the effect of years in current residence on familiarity with Proposition 13 (columns 1 through 4) or willingness to vote in favor of Proposition 13 again (columns 5 and 6). Because the Field Poll only asked homeowners the question regarding how long they have lived in their current residence, the results presented in Table 7 are based solely on the subsample of homeowners. In addition, because of the strong positive correlation between years in current residence and the age of respondents, we present results based on one specification that excludes age controls another specification that includes controls for a respondent's age. The results presented in Table 7 continue to suggest that homeowners that have lived in their current residence the longest are substantially more likely to be familiar with Proposition 13 than homeowners that recently purchased their home. In addition homeowners that have lived in their home the longest (more than 30 years) are substantially more likely to report a willingness to vote in favor of Proposition 13. Thus, taken together, the results presented in Tables 6 and 7 cast doubt on whether lack of homeowner knowledge regarding the property tax implications of Proposition 13 could be driving our results of a relatively stable aversion to the property tax among homeowners.

Aside from tax burden, another potential explanation for our results is that owner-occupants may oppose the property tax under the assumption that raising property taxes to provide additional spending on education or other productive publicly provided services may lower property values. Earlier research, however, works against this explanation. Brueckner $(1979,1982,1983)$ shows that in equilibrium efficiently delivered public service levels are consistent with property value maximization so that a change in property taxes accompanied by the associated increase in spending on local public goods should have no effect on property values. ${ }^{13}$ Further, if the property tax limitations imposed by Proposition 13 lowered spending below the level desired by jurisdiction residents, one would expect that increases in taxes that were dedicated to school spending would increase property values, weakening our estimated effects as opposed to explaining the negative relationship between homeownership and support

\footnotetext{
${ }^{13}$ Barrow and Rouse (2004) and Bates and Santerre (2003) apply this logic nationally and in the state of Connecticut, respectively, and conclude that school districts do not overspend on education, which would be required for this phenomena to explain our results.
} 
for the property tax. Brunner and Ross (2010) use data on repeated referenda on the voting threshold for school bond issues in California and show that voting patterns are consistent with public service levels being determined by the preferences of voters in income percentiles well below the median income, at least for school capital spending that is funded by the property tax. Cellini, Ferreira and Rothstein (2010) use a regression discontinuity analysis based on the fraction of voters supporting a school bond referenda to explicitly show that the passing of referenda leads to increases in housing prices in California school districts despite that fact that school bond issues are financed through property tax increases.

Another potential explanation behind our findings is that the strong opposition among homeowners to the property tax is being driven by the salience of the property tax relative to the sales tax for homeowners. Put differently, homeowners may simply react more strongly to the property tax due to the fact that property taxes are much more visible than sales taxes regardless of the actual relative tax burden faced. As Cabral and Hoxby (2012) note, homeowners typically write one or two checks a year to pay their property taxes, making those tax payments highly salient. In contrast, if a person wishes to understand how much they have paid in sales taxes over the past year, they must aggregate for themselves the sales tax payments made over a large number of purchases. As Cabral and Hoxby (2012) further note, the highly salient nature of the property tax may increase the perceived burdensomeness or offensiveness of the tax. Consistent with that notion they demonstrate that the decreased salience of the property tax that arises from placing property tax payments in escrow as part of a mortgage payment leads to higher property tax rates at the local level and lower rates of adoption of property tax limitations at the state level. While we cannot test for a causal impact of saliency on willingness to support the property tax, the large difference between homeowners and renters in the awareness of Proposition 13 is consistent with homeowners who are highly sensitized to the both the property tax and issues that affect the property tax.

\section{Conclusion and Discussion}

In this paper we use detailed micro-level survey data to provide new evidence on the renter illusion hypothesis. Using a difference-in-differences estimation strategy to control for individual specific preferences for public service spending, we find that renters are approximately 10 to 15 percentage points more likely than homeowners to favor a property tax increase over a sales tax increase to fund public services. However, these results are not driven by the voting behavior of renters. Renters appear to be indifferent between a property tax and a sales tax increase, while homeowners strongly oppose a property tax increase relative to a sales tax increase. Further, the indifference of renters between property and sales taxes persists for subsamples of low education, low income and younger renters, who might be less financially sophisticated. These results cast doubt on the strong version of the renter illusion hypothesis that suggests renters believe that they do not pay the property tax. Further analysis, based on both 
controlling for observable attributes associated with tax burden and on allowing the effect of homeownership to vary based on differential tax burden associated with Proposition 13, reveals that the strong opposition among homeowners to the property tax is not associated with the relative tax burden faced by the individual homeowner.

We consider three plausible explanations for why the strong opposition among homeowners to the property tax appears to be unrelated to an individual homeowner's tax burden, namely lack of voter knowledge concerning the property tax ramifications of Proposition 13, property tax capitalization and the salience of the property tax. We argue that our results are inconsistent with the theoretical and empirical evidence on property tax capitalization and provide evidence that homeowners are well aware of the property tax ramifications of Proposition 13. Thus, we conclude that the most plausible explanation for our results relates to the salience of the property tax relative to the sales tax for homeowners. As noted previously, homeowners may simply react more strongly to the property tax due to the fact that property taxes are much more visible than sales taxes regardless of the actual relative tax burden faced.

A number of other recent studies have documented asymmetric behavior between circumstance where taxes are salient and not salient (Finkelstein, 2009; Chetty, Looney and Kroft, 2009; Sausgruber and Tyran, 2005; Blumkin, Ruffle, and Ganun, 2012). A reasonable implication or suggestion that has been drawn from such results is that taxpayers may be making sub-optimal decisions when taxes are not salient and supporting the provision of an inefficiently high level of public services because they lack the information necessary to consider the personal costs associated with public service provision (Buchanan, 1967; Campbell, 2004; Caplan, 2001; Rothbard, 2002; in general and Oates, 2005 on the property tax). For example, in Cabral and Hoxby (2012), property tax rates are higher in areas where property tax payments are less visible and in Finkelstein (2009) equilibrium toll rates rise when tool facilities switch from using a cash payment method (which is fully observable to voters) to an electronic toll collection system.

While our paper does not directly show a relationship between salience and opposition to the property tax, our findings suggest that substantial caution be applied when considering the overprovision interpretation of the findings on tax salience and fiscal illusion. While salience is clearly associated with greater sensitivity to tax rates, such sensitivity is clearly no guarantee that taxpayers rationally consider their personal tax burden or effective tax price of public services when making choices concerning public service spending. As discussed above, our analysis of homeowners in California finds that homeowner aversion to the property tax has little to do with the individual burden of the property tax. Homeowners who have resided in the same home for 20 years or more and so are taxed on assessed values $1 / 3$ to $1 / 5$ the market values of their homes have the same dislike of the property tax as homeowners who have been in their home for less than 10 years. 


\section{References}

Banzhaf, S. H., Oates, W., 2012. On fiscal illusion and Ricardian equivalence in local public finance. National Tax Journal, forthcoming.

Barrow, L., Rouse, C., 2004. Using market valuation to assess public school spending. Journal of Public Economics 88, 1747-1769.

Bates, L. J., Santerre, R. E., 2003. The impact of a state mandated expenditure floor on aggregate property values. Journal of Urban Economics 53(3), 531-540.

Bergstrom, T. C., Goodman, R. P., 1973. Private demands for public goods. American Economic Review 63, 280-296.

Biegeleisen, J.A., Sjoquist, D. L., 1988. Rational voting applied to choice of taxes. Public Choice 57, 3947.

Blom-Hansen, J., 2005. Renter Illusion: Fact or Fiction? Urban Studies 42, 127-140.

Blumkin, T., Ruffle, B., Ganun, Y., 2012. Are income and consumption taxes ever really equivalent? Evidence from a real-effort experiment with real goods. European Economic Review 56(6), 12001219.

Brueckner, J., 1983. Property value maximization and public sector efficiency. Journal of Urban Economics 14(1), 1-15.

Brueckner, J., 1982. A test for allocative efficiency in the local public sector. Journal of Public Economics 19, 311-331.

Brueckner, J., 1979. Property values, local public expenditure and economic efficiency. Journal of Public Economics 11, 223-245.

Brunner, E., Ross, S., 2010. Is the median voter decisive? Evidence from referenda voting patterns. Journal of Public Economics 94, 898-910.

Brunner, E., Balsdon, E., 2004. Intergenerational conflict and the political economy of school spending. Journal of Urban Economics 56, 369-388.

Buchanan, James. 1967. Public Finance in Democratic Process; Fiscal Institutions and the Individual Choice. Chapel Hill, University of North Carolina Press.

Cabral, M., Hoxby, C., 2012. The hated property tax: Salience, tax rates, and tax revolts. NBER Working Paper No. 18514.

Campbell, R. J., 2004. Leviathan and fiscal illusion in overlapping jurisdictions. Public Choice 120, 30129.

Caplan, B., 2001. Rational irrationality and the microfoundations of political failure. Public Choice 107, 311-31. 
Cellini, S. R., Ferreira, F., Rothstein, J., 2010. The value of school facility investments: Evidence from a dynamic regression discontinuity design. Quarterly Journal of Economics 125 (1), 215-261.

Chetty, R., Looney, A., Kroft, K., 2009. Salience and taxation: Theory and evidence. American Economic Review 99(4), 1145-1177.

Corcoran, S., Evans, W.N., 2010. Income inequality, the median voter, and the support for public education. NBER Working Paper, 16097.

Cattaneo, M. A. and Wolter, S. C., 2009. Are the elderly a threat to educational expenditures? European Journal of Political Economy 25, 225-236.

Dollery, B. E., Worthington, A. C., 1996. The empirical analysis of fiscal illusion. Journal of Economic Surveys 10, 261-297.

Dollery, B. E., Worthington, A. C., 1999. Fiscal illusion at the local level: An empirical test using Australian municipal data. The Economic Record 75, 37-48.

Figlio, D. N., Fletcher, D., 2012. Suburbanization, demographic change and the consequences for school finance. Journal of Public Economics 96(11:12), 1144-1153.

Fletcher, D. Kenny, L. W., 2008. The Influence of the elderly on school spending in a median voter framework. Education Finance and Policy 3, 283-315.

Finkelstein, A., 2009. EZ-Tax: Tax Salience and Tax Rates. Quarterly Journal of Economics 124(3), 9691010.

Gemmell, N., Morrissey, O., Pinar, A., 2002. Fiscal illusion and political accountability: Theory and evidence from two local tax regimes in Britain. Public Choice 110(3:4), 199-224.

Heyndels, B., Smolders, C., 1994. Fiscal illusion at the local level: Empirical evidence for the Flemish municipalities. Public Choice 80(3:4), 325-338.

Lovell, M.C., 1978. Spending for education: the exercise of public choice. Review of Economics and Statistics 60, 487-495.

Martinez-Vazquez, J., 1983. Renters' illusion or savvy? Public Finance Quarterly 11, 237-247.

Oates, W. E., 1888. On the nature and measurement of fiscal illusion. In Taxation and Fiscal Federalism: Essays in Honor of Russell Mathews, G. Brennan et al., eds. Sydney, Australia: Australian National University Press, 65-82.

Oates, W. E., 2005. Property taxation and local public spending: The renter effect. Journal of Urban Economics 57, 419-431.

Reback, R., 2011. Local tax price discrimination in an aging society. Barnard College Working paper.

Reid, G. J., 1991. Tests of institutional versus non-institutional models of local public expenditure determination. Public Choice 70, 315-333.

Rothbard, M. N., 2002. Milton Friedman unraveled. The Journal of Libertarian Studies 16, 37-54. 
Rothstein, P., 1994. Learning the preferences of governments and voters from proposed spending and aggregate votes. Journal of Public Economics 54, 361-389.

Sausgruber, R., Tyran, J., 2008. Are we taxing ourselves? How deliberation and experience shape voting on taxes. Journal of Public Economics 95,164-176.

Sausgruber, R., Tyran, J., 2005. Testing the Mill hypothesis of fiscal illusion. Public Choice 122, 39-68.

Schokkaert, E., 1987. Preferences and demand for local spending. Journal of Public Economics 34, 175188.

Schwab, R.M., Zampelli, E. M., 1987. Disentangling the demand function from the production function for local public services: the case of public safety. Journal of Public Economics 33, 245-260.

Tsoodle, L.J., Turner, T.M., 2008. Property taxation and residential rents. Journal of Real Estate Economics 36(1), 63-80. 
Table 1

List of Variables and Sample Means

\begin{tabular}{|c|c|c|c|c|c|c|}
\hline & \multicolumn{2}{|c|}{$\begin{array}{l}(1) \\
\text { State Funding PPIC } \\
\end{array}$} & \multicolumn{2}{|c|}{$\begin{array}{l}\text { (3) } \\
\text { Local Funding PPIC } \\
\end{array}$} & \multicolumn{2}{|c|}{$\begin{array}{c}(5) \\
\text { State Funding Field Poll } \\
\end{array}$} \\
\hline & Renters & Homeowners & Renters & Homeowners & Renters & Homeowners \\
\hline Dependent Variables & & & & & & \\
\hline Rais e Property Tax & 0.301 & 0.226 & 0.608 & 0.371 & 0.257 & 0.148 \\
\hline Raise Sales Tax & 0.341 & 0.365 & 0.609 & 0.546 & 0.312 & 0.346 \\
\hline Independent Variables & & & & & & \\
\hline Age 45 to 54 & 0.178 & 0.270 & 0.154 & 0.261 & 0.122 & 0.208 \\
\hline Age 55 to 64 & 0.108 & 0.207 & 0.083 & 0.171 & 0.081 & 0.151 \\
\hline Age 65 or Older & 0.090 & 0.217 & 0.073 & 0.197 & 0.101 & 0.207 \\
\hline Associate Degree or Higher & 0.510 & 0.752 & 0.533 & 0.739 & 0.391 & 0.440 \\
\hline Female & 0.533 & 0.514 & 0.517 & 0.507 & 0.477 & 0.476 \\
\hline Black & 0.064 & 0.048 & 0.116 & 0.077 & 0.083 & 0.034 \\
\hline Hispanic & 0.415 & 0.188 & 0.440 & 0.228 & 0.204 & 0.133 \\
\hline Asian & 0.085 & 0.064 & 0.058 & 0.050 & 0.061 & 0.038 \\
\hline Children Under 18 & 0.401 & 0.362 & 0.412 & 0.372 & -- & -- \\
\hline Private School & 0.022 & 0.048 & 0.029 & 0.064 & -- & -- \\
\hline Income: $\$ 40,000-\$ 60,000$ & 0.172 & 0.156 & 0.161 & 0.163 & -- & -- \\
\hline Income: $\$ 60,000$ - $\$ 80,000$ & 0.076 & 0.144 & 0.085 & 0.143 & -- & -- \\
\hline Income: $\$ 80,000$ - $\$ 100,000$ & 0.045 & 0.135 & 0.038 & 0.125 & -- & -- \\
\hline Income: $\$ 100,000$ or higher & 0.062 & 0.284 & 0.056 & 0.244 & -- & -- \\
\hline Income: $\$ 20,000$ - $\$ 40,000$ & -- & -- & -- & -- & 0.411 & 0.287 \\
\hline Income: $\$ 40,000-\$ 60,000$ & -- & -- & -- & -- & 0.144 & 0.253 \\
\hline Income: $\$ 60,000$ or higher & -- & -- & -- & -- & 0.075 & 0.321 \\
\hline Observations & 873 & 1427 & 1524 & 2041 & 555 & 999 \\
\hline
\end{tabular}


Table 2

Cross Sectional Estimates

\begin{tabular}{|c|c|c|}
\hline & $\begin{array}{c}\text { (1) } \\
\text { State K12 Property Tax } \\
\end{array}$ & $\begin{array}{c}\text { (2) } \\
\text { Local K-12 Property Tax }\end{array}$ \\
\hline Renter & $\begin{array}{c}0.102 * * * \\
{[0.023]}\end{array}$ & $\begin{array}{c}0.192 * * * \\
{[0.019]}\end{array}$ \\
\hline Children Under 18 & $\begin{array}{l}-0.017 \\
{[0.021]}\end{array}$ & $\begin{array}{c}0.026 \\
{[0.019]}\end{array}$ \\
\hline Private School & $\begin{array}{l}-0.064 \\
{[0.048]}\end{array}$ & $\begin{array}{c}-0.083 * * \\
{[0.039]}\end{array}$ \\
\hline Age 45 to 54 & $\begin{array}{c}0.004 \\
{[0.024]}\end{array}$ & $\begin{array}{c}-0.059 * * * \\
{[0.022]}\end{array}$ \\
\hline Age 55 to 64 & $\begin{array}{c}0.008 \\
{[0.029]}\end{array}$ & $\begin{array}{c}-0.085 * * * \\
{[0.026]}\end{array}$ \\
\hline Age 65 or Older & $\begin{array}{c}-0.037 \\
{[0.030]}\end{array}$ & $\begin{array}{c}-0.076^{* * *} * \\
{[0.028]}\end{array}$ \\
\hline Associate Degree or Higher & $\begin{array}{c}0.045^{* *} \\
{[0.021]}\end{array}$ & $\begin{array}{c}0.003 \\
{[0.020]}\end{array}$ \\
\hline Income: $\$ 40,000$ - $\$ 60,000$ & $\begin{array}{c}0.010 \\
{[0.028]}\end{array}$ & $\begin{array}{c}-0.023 \\
{[0.025]}\end{array}$ \\
\hline Income: $\$ 60,000$ - $\$ 80,000$ & $\begin{array}{c}-0.003 \\
{[0.031]}\end{array}$ & $\begin{array}{c}-0.028 \\
{[0.029]}\end{array}$ \\
\hline Income: $\$ 80,000$ - $\$ 100,000$ & $\begin{array}{c}0.021 \\
{[0.035]}\end{array}$ & $\begin{array}{c}0.042 \\
{[0.033]}\end{array}$ \\
\hline Income: $\$ 100,000$ or higher & $\begin{array}{c}0.078 * * \\
{[0.031]}\end{array}$ & $\begin{array}{c}0.029 \\
{[0.028]}\end{array}$ \\
\hline Female & $\begin{array}{c}0.005 \\
{[0.018]}\end{array}$ & $\begin{array}{c}0.046 * * * \\
{[0.016]}\end{array}$ \\
\hline Black & $\begin{array}{c}-0.036 \\
{[0.039]}\end{array}$ & $\begin{array}{c}0.085 * * * \\
{[0.029]}\end{array}$ \\
\hline Hispanic & $\begin{array}{c}-0.012 \\
{[0.024]}\end{array}$ & $\begin{array}{c}0.098 * * * \\
{[0.022]}\end{array}$ \\
\hline Asian & $\begin{array}{l}0.070^{*} \\
{[0.038]}\end{array}$ & $\begin{array}{l}-0.028 \\
{[0.037]}\end{array}$ \\
\hline $\begin{array}{l}\text { Observations } \\
\text { R-squared }\end{array}$ & $\begin{array}{l}2331 \\
0.02\end{array}$ & $\begin{array}{l}3565 \\
0.08 \\
\end{array}$ \\
\hline
\end{tabular}

Notes: Each column presents estimates from a separate linear probability model. Dependent variables in column 1 is support for property tax increase to provide additional state-level funding for $\mathrm{K}-12$ education $(1=$ yes, $0=$ no). Dependent variable in columns 2 is support for property tax increase to provide additional local-level funding for K-12 education. Robust standard errors in brackets. * significant at $10 \% ; * *$ significant at $5 \% ; * * *$ significant at $1 \%$ 
Table 3

Difference-in-Differences Estimates

\begin{tabular}{|c|c|c|c|}
\hline & $\begin{array}{c}\text { (1) } \\
\text { State Property v. State Sales } \\
\text { (PPIC) } \\
\end{array}$ & $\begin{array}{c}\text { (2) } \\
\text { State Property v. State Sales } \\
\text { (Field Poll) }\end{array}$ & \begin{tabular}{|c} 
(3) \\
Local Property v. Local Sales \\
(PPIC) \\
\end{tabular} \\
\hline $\begin{array}{l}\text { Baseline } \\
\text { Renter }\end{array}$ & $\begin{array}{c}0.093 * * * \\
{[0.030]}\end{array}$ & $\begin{array}{c}0.096 * * * \\
{[0.035]}\end{array}$ & $\begin{array}{c}0.151 * * * \\
{[0.024]}\end{array}$ \\
\hline $\begin{array}{l}\text { County Fixed Effects } \\
\text { Renter }\end{array}$ & $\begin{array}{c}0.086 * * * \\
{[0.028]}\end{array}$ & $\begin{array}{c}0.083 * * \\
{[0.033]}\end{array}$ & $\begin{array}{c}0.148 * * * \\
{[0.023]}\end{array}$ \\
\hline $\begin{array}{l}\text { College Interaction } \\
\text { Renter } \\
\text { Renter*College }\end{array}$ & $\begin{array}{c}0.072^{*} \\
{[0.040]} \\
0.035 \\
{[0.051]} \\
\end{array}$ & $\begin{array}{c}0.104 * * \\
{[0.043]} \\
-0.020 \\
{[0.066]} \\
\end{array}$ & $\begin{array}{c}0.180 * * * \\
{[0.035]} \\
-0.047 \\
{[0.044]} \\
\end{array}$ \\
\hline $\begin{array}{l}\text { Income Interaction } \\
\text { Renter } \\
\text { Renter*Income } \$ 60,000 \text { or More (PPIC) } \\
\text { Renter*Income } \$ 40,000 \text { or More (Field Poll) } \\
\end{array}$ & $\begin{array}{c}0.092 * * * \\
{[0.034]} \\
0.006 \\
{[0.062]} \\
\end{array}$ & $\begin{array}{c}0.111 * * * \\
{[0.042]} \\
-0.046 \\
{[0.071]} \\
\end{array}$ & $\begin{array}{c}0.158^{* * *} \\
{[0.027]} \\
-0.024 \\
{[0.049]} \\
\end{array}$ \\
\hline $\begin{array}{l}\text { Age Interaction } \\
\text { Renter } \\
\text { Renter*Age } 45 \text { or Older }\end{array}$ & $\begin{array}{c}0.094 * * \\
{[0.039]} \\
-0.002 \\
{[0.052]}\end{array}$ & $\begin{array}{c}0.093 * * \\
{[0.044]} \\
0.006 \\
{[0.067]}\end{array}$ & $\begin{array}{c}0.145 * * * \\
{[0.031]} \\
0.014 \\
{[0.042]}\end{array}$ \\
\hline
\end{tabular}

Notes: Each column presents estimates from a separate regression where the dependent variable is the first difference between a respondents vote choice (yes/no) on two separate funding initiatives. Column (1) presents results from the PPIC survey that compares voter support for a state property tax increase to fund K-12 education to a state sales tax increase to fund K-12 education. Column (2) presents results from Field Poll surveys that compare voter support for a property tax increase to fund general state services to a state sales tax increase to fund general state services. Column (3) presents results from the PPIC surveys that compare voter support for a local property tax increase to fund K-12 education to a local sales tax increase to fund other local services. Panel 1 presents difference-in-differences estimates based on the specification given in Equation (1). Panel 2 adds county fixed effects to the baseline specification. Panel 3 adds an interaction term between the renter variable and an indicator variable for respondents with a college degree or higher. Panel 4 adds an interaction term betweeen the renter variable and an indicator variable for respondents with incomes of $\$ 60,000$ or more (PPIC surveys) or $\$ 40,000$ or more (Field Poll surveys). Panel 5 adds and interaction term between the renter variable and an indicator variable for respondents age 45 or older. All specifications include the full set of control variables listed in Table 1. Robust standard errors in brackets. * significant at $10 \% ; * *$ significant at $5 \%, * * *$ significant at $1 \%$ 
Table 4

Separate Estimates for Renters and Homeowners

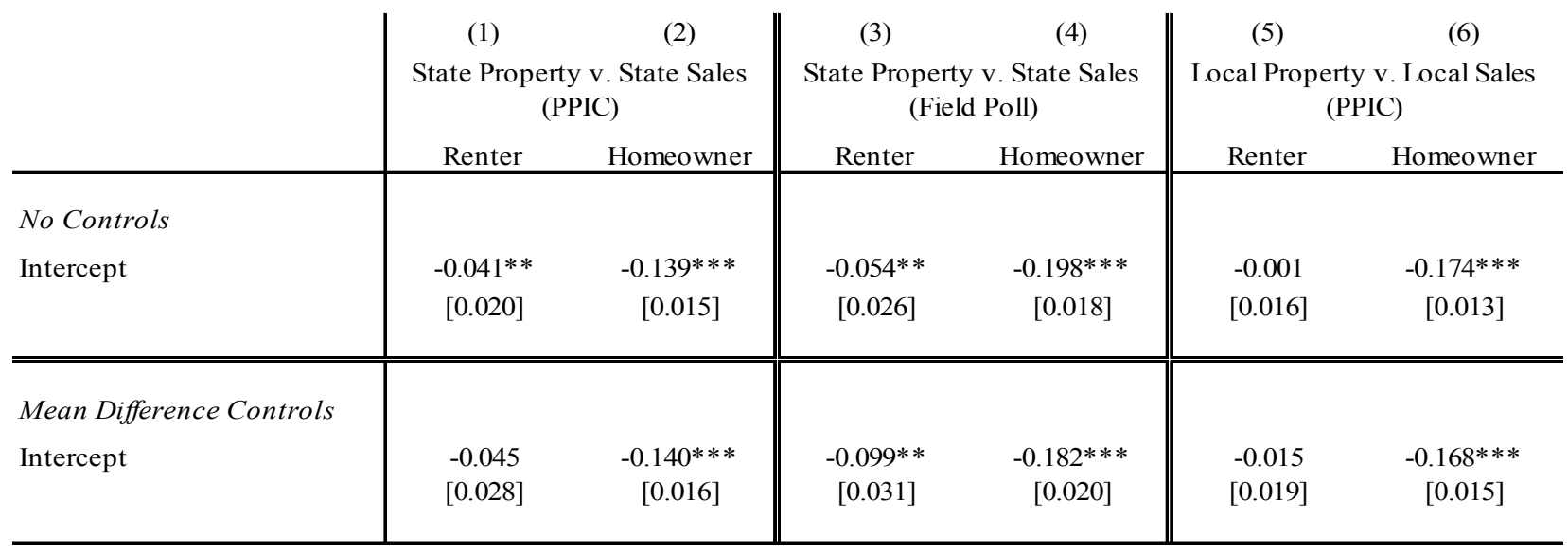

Notes: Each column presents estimates from a separate regression where the dependent variable is the first difference between a respondent's vote choice (yes/no) on two separate funding initiatives. Columns 1,3 and 5 present estimates based on the subsample of renters. Columns 2, 4 and 6 present estimates based on the subsample of homeowners. Panel 1 regresses the difference in support on a constant and no controls. Panel 2 regresses the difference in support on a constant and mean differenced control variables where the controls are the same as those reported in Table 2 less the renter indicator. Robust standard errors in brackets. $*$ significant at $10 \%, * *$ significant at $5 \%, * * *$ significant at $1 \%$. 
Table 5

Estimates Controlling for Years in Current Residence

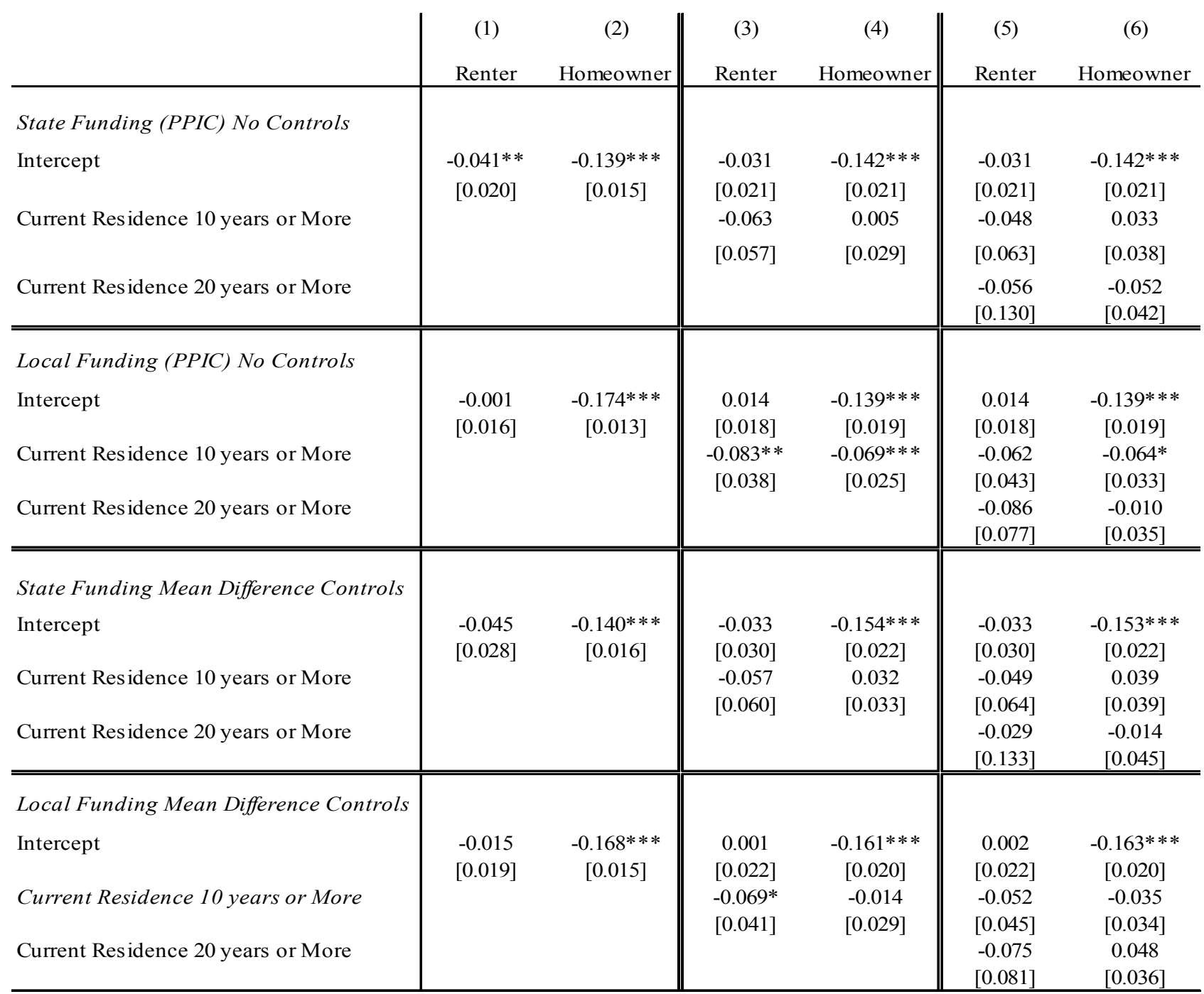

Notes: Each column presents estimates from a separate regression where the dependent variable is the first difference between a respondent's vote choice (yes/no) on two separate funding initiatives. Panels 1 and 3 present results that compare voter support for a state property tax increase to fund K-12 education to a state sales tax increase to fund K-12 education. Panels 2 and 4 present results that compare voter support for a local property tax increase to fund K-12 education to a local sales tax increase to fund police. Columns 1, 3 and 5 present estimates based on the subsample of renters. Columns 2, 4 and 6 present estimates based on the subsample of homeowners. Panels 1 and 2 regress the difference in support on a constant and no controls. Panels 3 and 4 regress the difference in support on a constant and mean differenced control variables where the controls are the same as those reported in Table 2 less the renter indicator. The specifications in columns 3 and 4 also include an indicator variable for whether a respondent has lived in their current residence for 10 years or more. Columns 5 and 6 adds an additional control for whether a respondent has lived in their current residence for 20 years or more. Robust standard errors in brackets. $*$ significant at $10 \%, * *$ significant at $5 \%, * * *$ significant at $1 \%$. 
Table 6

Familiarity with and Support for Proposition 13

\begin{tabular}{|c|c|c|c|c|c|c|c|}
\hline & \multicolumn{5}{|c|}{$\begin{array}{c}\text { Familiarity with Proposition } 13 \text { by Years in Current Residence, } \\
\text { Homeowners }\end{array}$} & \multirow[b]{2}{*}{$\begin{array}{r}\text { Owner's } \\
\text { Overall }\end{array}$} & \multirow[b]{2}{*}{$\begin{array}{c}\text { Renter' } \\
\text { Overal }\end{array}$} \\
\hline & $\begin{array}{l}\text { Less than } 5 \\
\text { years }\end{array}$ & $5-10$ years & $11-20$ years & $21-30$ years & $\begin{array}{c}\text { More than } 30 \\
\text { years }\end{array}$ & & \\
\hline Very familiar & $35.3 \%$ & $42.5 \%$ & $44.0 \%$ & $62.5 \%$ & $75.0 \%$ & $50.4 \%$ & $19.1 \%$ \\
\hline Somewhat familiar & 35.3 & 31.4 & 39.7 & 28.6 & 18.9 & 31.4 & 25.8 \\
\hline Not too familiar & 12.6 & 13.5 & 8.2 & 4.5 & 2.3 & 8.8 & 19.6 \\
\hline Not at all familiar & 16.8 & 12.6 & 8.2 & 4.5 & 3.8 & 9.4 & 35.6 \\
\hline Observations & 119 & 207 & 184 & 112 & 132 & 754 & 225 \\
\hline
\end{tabular}

Voting Preference if Proposition 13 Were Up for a Vote Again Today by Years in Current Residence, Homeowners

\begin{tabular}{l|ccccc||cc}
\multicolumn{1}{|c|}{} & \multicolumn{7}{|c||}{} \\
Would vote in favor & $55.0 \%$ & $64.4 \%$ & $63.6 \%$ & $68.4 \%$ & $79.5 \%$ & $66.0 \%$ & $43.2 \%$ \\
Would vote against & 29.2 & 20.7 & 29.9 & 21.1 & 14.4 & 23.2 & 24.2 \\
Don't know & 15.8 & 14.9 & 6.5 & 10.5 & 6.1 & 10.8 & 32.6 \\
\hline Observations & 120 & 208 & 184 & 114 & 132 & 758 & 227 \\
\hline
\end{tabular}


Table 7

Estimates for Familiarity with and Support for Proposition 13

\begin{tabular}{|c|c|c|c|c|c|c|}
\hline \multirow[b]{2}{*}{ Variable } & (1) & & (3) & (4) & & (6) \\
\hline & $\begin{array}{c}\text { Very } \\
\text { Familiar }\end{array}$ & $\begin{array}{c}\text { Very } \\
\text { Familiar }\end{array}$ & $\begin{array}{c}\text { ith Prop. } 13 \\
\text { Very or } \\
\text { Somewhat } \\
\text { Familiar } \\
\end{array}$ & $\begin{array}{c}\text { Very or } \\
\text { Somewhat } \\
\text { Familiar } \\
\end{array}$ & $\underline{\text { Would Vot }}$ & For Prop. 13 \\
\hline \multicolumn{7}{|l|}{ Years in Current Residence } \\
\hline $5-10$ years & $\begin{array}{l}0.086^{*} \\
{[0.049]}\end{array}$ & $\begin{array}{l}0.084^{*} \\
{[0.048]}\end{array}$ & $\begin{array}{c}0.025 \\
{[0.039]}\end{array}$ & $\begin{array}{c}0.016 \\
{[0.038]}\end{array}$ & $\begin{array}{l}0.084^{*} \\
{[0.050]}\end{array}$ & $\begin{array}{c}0.075 \\
{[0.051]}\end{array}$ \\
\hline $11-20$ years & $\begin{array}{c}0.117^{* *} \\
{[0.053]}\end{array}$ & $\begin{array}{c}0.023 \\
{[0.053]}\end{array}$ & $\begin{array}{c}0.124 * * * \\
{[0.041]}\end{array}$ & $\begin{array}{c}0.053 \\
{[0.042]}\end{array}$ & $\begin{array}{l}0.093 * \\
{[0.054]}\end{array}$ & $\begin{array}{c}0.065 \\
{[0.056]}\end{array}$ \\
\hline $21-30$ years & $\begin{array}{c}0.334 * * * \\
{[0.061]}\end{array}$ & $\begin{array}{c}0.158 * * \\
{[0.064]}\end{array}$ & $\begin{array}{c}0.217 * * * \\
{[0.048]}\end{array}$ & $\begin{array}{c}0.100 * * \\
{[0.051]}\end{array}$ & $\begin{array}{l}0.115^{*} \\
{[0.062]}\end{array}$ & $\begin{array}{c}0.059 \\
{[0.067]}\end{array}$ \\
\hline $\begin{array}{l}\text { More than } 30 \text { years } \\
\text { Controls }\end{array}$ & $\begin{array}{c}0.463 * * * \\
{[0.061]}\end{array}$ & $\begin{array}{c}0.260 * * * \\
{[0.065]}\end{array}$ & $\begin{array}{c}0.265 * * * \\
{[0.048]}\end{array}$ & $\begin{array}{c}0.128 * * \\
{[0.052]}\end{array}$ & $\begin{array}{c}0.251 * * * \\
{[0.062]}\end{array}$ & $\begin{array}{c}0.175^{* *} \\
{[0.069]}\end{array}$ \\
\hline School-Age Children & $\begin{array}{c}0.011 \\
{[0.034]}\end{array}$ & $\begin{array}{l}0.057^{*} \\
{[0.034]}\end{array}$ & $\begin{array}{c}0.015 \\
{[0.027]}\end{array}$ & $\begin{array}{c}0.039 \\
{[0.027]}\end{array}$ & $\begin{array}{c}-0.009 \\
{[0.035]}\end{array}$ & $\begin{array}{c}0.005 \\
{[0.036]}\end{array}$ \\
\hline Bachelor's Degree or Higher & $\begin{array}{c}0.103 * * * \\
{[0.036]}\end{array}$ & $\begin{array}{c}0.097 * * * \\
{[0.035]}\end{array}$ & $\begin{array}{c}0.100 * * * \\
{[0.028]}\end{array}$ & $\begin{array}{c}0.097 * * * \\
{[0.028]}\end{array}$ & $\begin{array}{c}-0.101 * * * \\
{[0.037]}\end{array}$ & $\begin{array}{c}-0.098 * * * \\
{[0.037]}\end{array}$ \\
\hline Income: $\$ 20,000$ - $\$ 40,000$ & $\begin{array}{l}-0.091 \\
{[0.088]}\end{array}$ & $\begin{array}{c}-0.083 \\
{[0.086]}\end{array}$ & $\begin{array}{c}0.046 \\
{[0.069]}\end{array}$ & $\begin{array}{c}0.057 \\
{[0.069]}\end{array}$ & $\begin{array}{l}-0.042 \\
{[0.090]}\end{array}$ & $\begin{array}{l}-0.028 \\
{[0.092]}\end{array}$ \\
\hline Income: $\$ 40,000$ - $\$ 60,000$ & $\begin{array}{c}0.084 \\
{[0.088]}\end{array}$ & $\begin{array}{c}0.086 \\
{[0.086]}\end{array}$ & $\begin{array}{c}0.174 * * \\
{[0.069]}\end{array}$ & $\begin{array}{c}0.178 * * * \\
{[0.069]}\end{array}$ & $\begin{array}{c}0.179 * * \\
{[0.090]}\end{array}$ & $\begin{array}{c}0.187 * * \\
{[0.092]}\end{array}$ \\
\hline Income: $\$ 60,000$ - $\$ 80,000$ & $\begin{array}{c}0.006 \\
{[0.087]}\end{array}$ & $\begin{array}{c}0.090 \\
{[0.086]}\end{array}$ & $\begin{array}{c}0.138^{* *} \\
{[0.069]}\end{array}$ & $\begin{array}{c}0.200 * * * \\
{[0.068]}\end{array}$ & $\begin{array}{c}0.061 \\
{[0.089]}\end{array}$ & $\begin{array}{c}0.081 \\
{[0.091]}\end{array}$ \\
\hline Income: $\$ 80,000$ or higher & $\begin{array}{c}0.041 \\
{[0.081]}\end{array}$ & $\begin{array}{c}0.103 \\
{[0.080]}\end{array}$ & $\begin{array}{c}0.219 * * * \\
{[0.064]}\end{array}$ & $\begin{array}{c}0.262 * * * \\
{[0.064]}\end{array}$ & $\begin{array}{l}0.137^{*} \\
{[0.083]}\end{array}$ & $\begin{array}{c}0.172 * * \\
{[0.085]}\end{array}$ \\
\hline Female & $\begin{array}{c}-0.129 * * * \\
{[0.034]}\end{array}$ & $\begin{array}{c}-0.130 * * * \\
{[0.033]}\end{array}$ & $\begin{array}{c}-0.115^{* * *} * \\
{[0.027]}\end{array}$ & $\begin{array}{c}-0.115 * * * \\
{[0.027]}\end{array}$ & $\begin{array}{c}-0.052 \\
{[0.035]}\end{array}$ & $\begin{array}{c}-0.053 \\
{[0.035]}\end{array}$ \\
\hline White & $\begin{array}{c}0.213 * * * \\
{[0.040]}\end{array}$ & $\begin{array}{c}0.160 * * * \\
{[0.040]}\end{array}$ & $\begin{array}{c}0.263 * * * \\
{[0.031]}\end{array}$ & $\begin{array}{c}0.232 * * * \\
{[0.032]}\end{array}$ & $\begin{array}{c}0.091 * * \\
{[0.041]}\end{array}$ & $\begin{array}{c}0.070 \\
{[0.043]}\end{array}$ \\
\hline Age 45 to 54 & & $\begin{array}{c}0.184 * * * \\
{[0.046]}\end{array}$ & & $\begin{array}{c}0.142 * * * \\
{[0.037]}\end{array}$ & & $\begin{array}{c}0.030 \\
{[0.049]}\end{array}$ \\
\hline Age 55 to 64 & & $\begin{array}{c}0.349 * * * \\
{[0.053]}\end{array}$ & & $\begin{array}{c}0.213 * * * \\
{[0.043]}\end{array}$ & & $\begin{array}{c}0.080 \\
{[0.057]}\end{array}$ \\
\hline Age 65 or Older & & $\begin{array}{c}0.402 * * * \\
{[0.055]}\end{array}$ & & $\begin{array}{c}0.272 * * * \\
{[0.044]} \\
\end{array}$ & & $\begin{array}{c}0.143^{* *} \\
{[0.058]} \\
\end{array}$ \\
\hline Observations & 754 & 730 & 754 & 730 & 758 & 734 \\
\hline R-squared & 0.167 & 0.236 & 0.218 & 0.266 & 0.061 & 0.069 \\
\hline
\end{tabular}

Notes: Each column presents estimates from a separate linear probability model. Dependent variables in columns 1 and 2 equals one if voter is very familiar with Proposition 13 and zero otherwise. Dependent variable in columns 3 and 4 equals one if voter is very or somewhat familiar with Proposition 13 and zero otherwise. Dependent variable in columns 5 and 6 is voting preference if Proposition 13 were up for a vote again today $(1=$ vote yes, $0=$ vote no or don't know). * significant at $10 \% ; * *$ significant at $5 \% ; * * *$ significant at $1 \%$ 